Jurnal PG-PAUD Trunojoyo : Jurnal Pendidikan dan Pembelajaran Anak Usia Dini, Volume 6, Nomor 2, Oktober 2019, hal $70-76$, ISSN : 2528-3553 (online), ISSN: 2407-4454 (print)

\title{
HUBUNGAN KOMUNIKASI GURU DAN ANAK DENGAN KEDISIPLINAN PADA KELOMPOK B
}

\author{
Binti Ni'matul Muthoharoh \\ Siti Fadjryana Fitroh \\ Dewi Mayangsari \\ Program Studi Pendidikan Guru Pendidikan Anak Usia Dini Universitas Trunojoyo Madura \\ Email: binti.nikmah7@gmail.com, fadjryana.fitroh@trunojoyo.ac.id,mayangsarie@gmail.com
}

\author{
Received (Bulan Juni 2019), Accepted (Bulan Agustus 2019), Published (Bulan Oktober 2019)
}

\begin{abstract}
The aim of this research to determine the correlation of communication between teachers and children with discipline of group B in Sejahtera Kamal kindergarten. This type of research is quantitative correlation design. The sampling technique used nonprobability samples with the type of saturated sample of 16 samples. Data collection techniques using observation, questionnaires, and documentation. Observation sheet used to measure variables discipline children at school and questionnaires used to measure the communication variables of teachers and children. Documentation use to photo of activities. Data were analyzed using Pearson Product Moment Correlation to test the hypothesis. The results showed that no significant relationship between teacher and child communication discipline within the group B in Sejahtera Kamal kindergarten. The result of the data analysis Pearson Product Moment Correlation was obtained for $r_{\text {hitung }}=0,205$. With a large contribution of communication between the teacher and the child ie $K D=r^{2} \times 100 \%=(0,205)^{2} \times 100 \%=0,042 \%$. Thus, it can be concluded that the communication between the teacher and the child is lower correlation with the discipline of group B in Sejahtera Kamal kindergarten.
\end{abstract}

Keywords: Communication Between Teachers and Children, Discipline, Group B.

\begin{abstract}
Abstrak: Penelitian ini bertujuan untuk mengetahui hubungan komunikasi antara guru dan anak dengan kedisiplinan pada kelompok B di TK Sejahtera Kamal.. Jenis penelitian ini adalah kuantitatif dengan desain korelasi. Teknik pengambilan sampel menggunakan nonprobability sampel dengan jenis sampel jenuh sebanyak 16 sampel. Teknik pengambilan data menggunakan observasi, angket, dan dokumentasi. Lembar observasi digunakan untuk mengukur variabel disiplin anak di sekolah dan angket digunakan untuk mengukur variabel komunikasi guru dan anak. Dokumentasi berupa foto kegiatan. Teknik analisis data menggunakan korelasi Pearson Product Moment untuk pengujian hipotesis. Hasil penelitian ini menunjukkan bahwa tidak ada hubungan yang signifikan antara komunikasi guru dan anak terhadap kedisiplinan pada kelompok B di TK Sejahtera Kamal. Hasil analisis data korelasi Pearson Product Moment diperoleh sebesar rhitung $=0,205$ dengan besar sumbangan dari komunikasi antara guru dan anak yaitu $K D=r^{2} \times 100 \%=(0,205)^{2} \times 100 \%=0,042 \%$. Jadi, dapat disimpulkan bahwa komunikasi antara guru dan anak tidak terdapat hubungan yang signifikan dengan kedisiplinan pada kelompok B di TK Sejahtera Kamal.
\end{abstract}

Kata Kunci : Komunikasi Antara Guru dan Anak, Kedisiplinan, Kelompok B.

\section{PENDAHULUAN}

Komunikasi merupakan hal yang tidak dapat terpisahkan dari seluruh aktivitas manusia, baik secara individu ataupun kelompok. Ngainum Naim (2011:50) ia menyatakan bahwa hanya dengan komunikasi lah yang dapat menyentuh segala aspek kehidupan, dan menentukan kualitas hidup kita. Demikian pula dengan manusia yang tidak bisa lepas dari orang lain, mereka saling berinteraksi satu sama lain dan saling bertukar pesan. Oleh karena itu komunikasi menjadi salah satu hal terpenting dalam suatu hubungan di lingkungan masyarakat terlebih di lingkungan sekolah.
Pendidikan merupakan suatu komunikasi jika ditinjau dari prosesnya. Memiliki arti bahwa dalam proses tersebut terlibat dua komponen yang terdiri atas manusia, yakni guru sebagai komunikator dan anak didik sebagai komunikan. Komunikasi pendidikan memiliki pengertian sendiri yaitu proses perjalanan pesan atau informasi yang merambah bidang atau peristiwa-peristiwa pendidikan. Ngainum Naim (2011:27) menyatakan bahwa pada posisi ini komunikasi tidak lagi bebas atau netral, tetapi dikendalikan dan dikondisikan untuk tujuan-tujuan pendidikan. Guru memiliki peran penting dalam manajemen suasana kelas, karena dengan adanya pesan-pesan ataupun nasehat 
Jurnal PG-PAUD Trunojoyo : Jurnal Pendidikan dan Pembelajaran Anak Usia Dini, Volume 6, Nomor 2, Oktober 2019, hal 70 - 76, ISSN : 2528-3553 (online), ISSN: 2407-4454 (print)

melalui komunikasi yang disampaikan oleh guru kepada anak didik, diharapkan dapat mempengaruhi perilaku mereka. Oleh karenanya guru harus menanamkan nilai-nilai karakter sekaligus mengembangkan potensi dan bakat anak secara optimal.

Potensi yang dimiliki oleh setiap anak tidaklah sama, anak memiliki keunikan masing-masing yang mana orang tua dan guru harus memahami itu. Menurut Mulyasa (2012:20) ia mengungkapkan bahwa anak merupakan manusia kecil yang memiliki sifat unik, meskipun lahir kembar mereka dilahirkan dengan potensi yang berbeda, memiliki kelebihan, bakat, dan minat masingmasing, sehingga dibutuhkannya pendidikan yang juga dapat mengembangkan karakternya. Oleh sebab itu, penanaman nilai-nilai karakter harus dilakukan oleh orang tua dan guru sedini mungkin agar anak terbiasa melakukan kebiasaan baik dimanapun mereka berada.

Perilaku disiplin seperti kepatuhan dan ketertiban pada anak memang berbeda-beda, ada yang terbiasa tepat waktu ada yang tidak, ada yang patuh dan ada yang kurang patuh. Hal tersebut dapat terjadi karena terdapat beberapa faktor yang mempengaruhinya yaitu; kesadaran diri, mengikuti dan menaati aturan, alat pendidikan, dan hukuman. Tulus Tu'u (2008:33) berpendapat disiplin adalah alat pendidikan untuk mempengaruhi, mengubah, membina dan membentuk perilaku sesuai dengan nilai-nilai yang ditentukan atau diajarkan. Sehingga dalam pengajaran disiplin pada anak usia dini dibutuhkan salah satu media perantara yakni komunikasi. Penggunaan media komunikasi dalam penyampaian nilai-nilai karakter pada diri anak dianggap efisien karena mampu mempengaruhi perilaku mereka.

Adapun keterkaitan antara komunikasi dengan disiplin menurut penelitian yang dilakukan oleh Ulil Ma'arif ia menyatakan bahwa komunikasi yang dilakukan oleh orang tua-remaja dapat memengaruhi tingkat disiplinnya di sekolah. Jika komunikasi yang dilakukan semakin intens antara keduanya maka tingkat disiplin mereka juga akan tinggi. Namun jika komunikasi antara keduanya tidak begitu intens maka tingkat disiplin anak akan rendah. Begitu pula dengan komunikasi yang dilakukan guru-anak, akan dapat memberikan dampak pada perilaku disiplin mereka di sekolah.
Adapun pola komunikasi yang dapat diterapkan oleh guru agar hubungan intepersonal dengan anak menjadi baik menurut Nana Sudjana (2003:31) yakni pola komunikasi satu arah, pola komunikasi dua arah dan pola komunikasi sebagai transaksi. Pola komunikasi tersebut memiliki kelebihan dan kekurangan masing-masing, sehingga guru perlu mempertimbangkan dengan matang pola komunikasi mana yang harus diterapkan. Karena dengan penggunaan pola komunikasi yang tepat dapat mempermudah penyampaian pesan bahkan mempengaruhi perilaku anak.

Ada pula indikator dalam pemberian nasehat ataupun pesan pada anak melalui komunikasi yang efektif menurut Suranto (2006:37) diantaranya pemahaman, kesenangan, pengaruh pada sikap, hubungan yang makin baik, dan tindakan kedua belah pihak. Diantara indikator-indikator tersebut, seorang guru dapat menerapkannya dalam proses kegiatan pembelajaran sehari-hari. Supaya proses pembelajaran berjalan secara efektif dan efisien, terutama dalam menanamkan karakter disiplin pada anak.

Pendisiplinan pada anak tidaklah mudah dilakukan di sekolahan jika proses tersebut tidak dibarengi dengan dukungan dari orang tua dirumah. Tujuan adanya disiplin pada anak usia dini sendiri menurut Syilvia Rimm (2003:47) yakni untuk mengarahkan pada anak supaya mereka belajar tentang hal baik yang merupakan bagian dari persiapan masa dewasa, saat mereka bergantung pada disiplin diri. Diharapkan, kelak disiplin diri mereka akan membuat hidup mereka bahagia, berhasil, dan penuh kasih sayang. Oleh karena hal tersebut perilaku disiplin sudah harus tertanam dalam diri anak sejak usia dini.

Selain itu ada beberapa aspek yang harus diperhatikan oleh guru dalam menanamkan perilaku disiplin pada anak usia dini. Menurut Tri Na'imah (2005:55) ia menyatakan bahwa ada tiga aspek disiplin yakni kontrol diri, keteraturan diri dan pemahaman norma. Aspek-aspek tersebut harus dipertimbangkan dalam penanaman disiplin pada anak usia dini, terlebih dalam aspek keteraturan diri anak.

Pada aspek disiplin tersebut terdapat pula indikator disiplin pada anak usia dini menurut Harun (2012:20) yaitu; 1) selalu datang tepat waktu, 2) dapat memperkirakan waktu yang diperlukan untuk menyelesaikan sesuatu, 3) menggunakan benda sesuai dengan fungsinya, 
72 Jurnal PG-PAUD Trunojoyo : Jurnal Pendidikan dan Pembelajaran Anak Usia Dini, Volume 6, Nomor 2, Oktober 2019, hal 70-76, ISSN : 2528-3553 (online), ISSN: 2407-4454 (print)

4) mengambil dan mengembalikan benda pada tempatnya, 5) berusaha menaati aturan yang telah disepakati, dan 6) tertib menunggu giliran serta menyadari akibat bila tidak disiplin. Adanya indikator dari perilaku disiplin ini, dapat menjadi tolak ukur guru dalam melihat atau mengamati kemampuan berdisiplin seorang anak.

Berdasarkan hasil pengamatan pada saat kegiatan PLP II (Praktik Lapangan Persekolahan II) di TK Sejahtera Kamal pada tanggal 16 Juli - 6 September tahun 2018, menunjukkan bahwa masih kurangnya kedisiplinan pada anak kelompok B2. Hal ini terlihat dari kebiasaan mereka saat mengikuti proses belajar di sekolah, dimana beberapa anak masih terlambat datang sekolah, makan diwaktu pembelajaran berlangsung, mengganggu teman yang sedang mengerjakan, bermain sendiri, keluar masuk kelas diwaktu pembelajaran dan tidak mengerjakan tugasnya sampai selesai. Saat sikap berdoa, ada anak yang tidak mengikuti sikap berdoa dan ada yang masih sibuk dengan tasnya, pada waktu circle time guru memberikan nasehat pada anak untuk mengikuti kegiatan berdo'a dengan sikap yang baik dan benar.

Berdasarkan masalah yang dihadapi, membuat peneliti tertarik untuk mengamati tentang permasalahan ini dan ingin mengetahui lebih jauh tentang keterkaitan komunikasi antara guru-anak dengan perilaku disiplin anak. Peneliti menduga bahwa ada hubungan antara kedisiplinan anak di sekolah dengan komunikasi yang dilakukan oleh guruanak. Oleh karena itu peneliti mengajukan penelitian dengan judul "Hubungan Komunikasi Antara Guru dan Anak Dengan Kedisiplinan Pada Kelompok B di TK Sejahtera Kamal."

\section{METODE}

Metode penelitian yang digunakan dalam penelitian ini yaitu menggunakan pendekatan kuantitatif. Sugiyono (2014:7) menyatakan bahwa penelitian kuantitatif merupakan metode penelitian tradisional, karena metode ini sudah cukup lama digunakan sehingga sudah mentradisi sebagai metode untuk penelitian. Dinamakan metode kuantitatif karena data penelitian ini berupa angka-angka dan analisis menggunakan statistik.

Teknik penelitian pada penelitian ini menggunakan teknik kolerasional. Arikunto
(2014:313) mengungkapkan bahwa studi kolerasi merupakan suatu penelitian yang dilakukan untuk mengetahui suatu hubungan antara variabe yang diteliti, dan apabila ada seberapa erat hubungannya serta berarti atau tidak hubungan tersebut. Penelitian ini bertujuan untuk melihat adanya hubungan komunikasi antara guru dan anak dengan kedisiplinan anak.

Sumber data penelitian ini menggunakan sampel jenuh. Sugiyono (2014: 84) menyatakan bahwa sampel jenuh ialah teknik penentuan sampel bila semua anggota populasi digunakan sebagai sampel. Teknik sampling ini sering digunakan oleh peneliti jika jumlah populasi relatif sedikit, kurang dari 30 orang, atau penelitian yang ingin membuat generalisasi dengan kesalahan yang sangat kecil. Sampel pada penelitian ini yaitu seluruh anak kelompok B2 TK Sejahtera Kamal yaitu sebanyak 16 anak dan satu guru kelas sebagai sumber data.

Teknik pengumpulan data pada penelitian ini menggunakan observasi, kuesioner, dan dokumentasi. Observasi yang digunakan yaitu melalui observasi nonpartisipan. Observasi yang dilakukan dimana peneliti tidak terlibat dalam kegiatan dan hanya sebagai pengamat saja. Data diperoleh dari pengamat satu dan pengamat dua sebagai pembanding. Data dari pengamat satu dan dua tersebut yang akan dihitung. Kuesioner pada penelitian ini diberikan kepada orang tua atau wali murid kelompok B2 TK Sejahtera Kamal. Dokumentasi penelitian ini digunakan sebagai data pendukung untuk memperjelas dan memperkuat data penelitian yang telah dilakukan oleh peneliti.

Teknik analisis data pada penelitian ini menggunakan korelasi pearson product moment. Penggunaan analisis korelasi parson product moment karena data berbentuk interval. Riduwan (2015:80) menyatakan bahwa penggunaan analisis korelasi pearson product moment yaitu untuk mengetahui derajat hubungan antara variabel bebas (independent) dengan variabel terikat (dependent).

Adapun rumus korelasi pearson product moment (Riduwan: 2015:80) yakni: 
Jurnal PG-PAUD Trunojoyo : Jurnal Pendidikan dan Pembelajaran Anak Usia Dini, Volume 6, Nomor 2, Oktober 2019, hal 70 - 76, ISSN : 2528-3553 (online), ISSN: 2407-4454 (print)

$$
r_{\text {hitung }}=\frac{n\left(\sum X Y\right)-\left(\sum X\right) \cdot\left(\sum Y\right)}{\sqrt{\left\{n \cdot \sum X^{2}-\left(\sum X\right)^{2}\right\}\left\{n \cdot \sum Y^{2}-\left(\sum Y\right)^{2}\right\}}}
$$

Keterangan:

$r_{\text {hitung }}$ : Koefisien Korelasi

$\Sigma \mathrm{X} \quad$ : Jumlah Skor Total Variabel X

$\Sigma \mathrm{Y} \quad$ : Jumlah Skor Total Variabel Y

n : Jumlah responden

Selanjutnya untuk menyatakan besar kecilnya sumbangan variabel $\mathrm{X}$ terhadap $\mathrm{Y}$ dapat ditentukan dengan rumus koefisien diterminan sebagai berikut:

$$
K D=r^{2} \times 100 \%
$$

Keterangan:

KD : Nilai Koefisien Determinan

$\mathrm{r}$ : Nilai Koefisien Korelasi

Persyaratan analisis uji korelasi pearson product moment diantaranya yaitu data berdistribusi normal dan data berpola linear.

\section{HASIL DAN PEMBAHASAN Hasil}

Kegiatan pembelajaran yang dilakukan dalam penelitian ini melalui kegiatan pembelajaran seperti biasa. Kegiatan pembelajaran berlangsung di dalam kelas maupun di luar kelas. Penggunaan komunikasi berlangsung dalam kelompok kecil, ketika kegiatan circle time berlangsung.

Komunikasi efektif yang dilakukan oleh guru dan anak di TK Sejahtera Kamal dilakukan dengan cara pengelompokkan. Pengelompokkan dilakukan untuk mengelompokkan subjek penelitian kedalam 5 indikator dari komunikasi efektif, yaitu pemahaman, kesenangan, pengaruh pada sikap, tindakan kedua belah pihak, dan hubungan yang makin baik. Pengelompokkan data dilakukan dengan cara scoring dengan bantuan Microsoft Excel secara terpisah pada pernyataan-pernyataan yang mewakili setiap bagian dari kelima indikator komunikasi yang efektif tersebut. Sehingga setiap subjek memperoleh empat skor pada instrumen komunikasi guru dan anak. Skor tertinggi yang dimiliki setiap subjek penelitian (sampel) akan menunjukkan kecenderungan komunikasi efektif yang dilakukan oleh guru pada siswanya.
Dari hasil perhitungan menunjukkan bahwa setiap komunikasi efektif yang digunakan oleh guru mendapat respon baik dari siswa. Karena tiga dari indikator komunikasi efektif memiliki jumlah sama yaitu masing-masing 4 siswa. Komunikasi efektif melalui pemberian pemahaman pada anak ada 4 siswa, melalui kesenangan ada 4 siswa, dan melalui tindakan kedua belah pihak ada 4 siswa. Sedangkan untuk pengaruh pada sikap hanya ada 2 siswa dan hubungan yang makin baik juga ada 2 siswa.

Dapat disimpulkan bahwa siswa kelompok B2 di TK Sejahtera Kamal yang menjadi subjek penelitian sebagian besar memberikan respon pada guru melalui komunikasi yang menyenangkan, pemberian pemahaman dan tindakan dari kedua belah pihak. Komunikasi yang dilakukan guru dapat memberikan dampak positif pada anak didik jika cara guru mengkomunikasikan melalui cara yang menyenangkan, pemberian pemahaman pada anak dan tindakan guru pada anak.

Dari hasil perhitungan presentase komunikasi efektif antara guru dan anak diperoleh hasil bahwa siswa yang merespon atau tanggap dengan informasi atau nasehat dari guru dengan cara menyenangkan sebanyak 4 siswa (25\%). Siswa yang tanggap pada guru melalui pemahaman sebanyak 4 dari 16 siswa (25\%). Siswa yang tanggap pada guru melalui hubungan yang makin baik sebanyak 2 dari 16 siswa (13\%). Siswa yang tanggap pada guru melalui pengaruh pada sikap sebanyak 2 dari 16 siswa (12\%) dan siswa yang tanggap pada guru melalui tindakan kedua belah pihak sebanyak 4 dari 16 siswa (25\%).

Penggunaan komunikasi yang efektif tersebut menghasilkan data perilaku disiplin anak yang dominan mencapai kategori Berkembang Sesuai Harapan (BSH). Hasil perhitungan kedisiplinan anak diperoleh data sebesar $12 \%$ anak masuk dalam kategori Berkembang Sangat Baik (BSB) dan 88\% anak masuk kategori Berkembang Sesuai Harapan (BSH). Sehingga kedisiplinan anak kelompok B TK Sejahtera Kamal sudah dapat dikatakan berkembang dengan baik.

Setelah selesai uji prasyarat analisis data pada penelitian ini yaitu berupa uji normalitas data dan uji linieritas data, dihasilkan data berdistribusi normal dan berpola linier maka 
74 Jurnal PG-PAUD Trunojoyo : Jurnal Pendidikan dan Pembelajaran Anak Usia Dini, Volume 6, Nomor 2, Oktober 2019, hal 70-76, ISSN : 2528-3553 (online), ISSN: 2407-4454 (print)

analisis korelasi dapat dilanjutkan. Taraf kesalahan pengujian analisis data $\alpha=0,05(5 \%)$ diperoleh nilai $\mathrm{r}$ sebesar 0,205 . Berdasarkan perhitungan analisis data tersebut dapat diperoleh nilai $\mathrm{Ho}$, maka terima $\mathrm{Ho}$, sehingga tidak terdapat hubungan antara komunikasi guru dan anak dengan kedisiplinan anak.

Besar kontribusi komunikasi guru dan anak dengan kedisiplinan anak dapat dihitung sebagai berikut: $K D=r^{2} \times 100 \%=$ $(0,205)^{2} \times 100 \%=0,042 \%$. Pada penelitian ini dapat diketahui bahwa komunikasi guru dan anak terdapat hubungan sebesar 0,042\% dengan kedisiplinan anak kelompok B2 TK Sejahtera Kamal. Kedisiplinan anak sebesar 99,96\% dipengaruhi oleh faktor lain.

\section{Pembahasan}

Penelitian ini dilakukanidi sekolah TK Sejahtera Kamal pada anak kelompok B. Tujuan dilakukannya penelitian ini yaitu untuk mengetahui hubunganidari komunikasiiantara guru dan anak dengan kedisiplinan pada anak kelompok B di TK Sejahtera Kamal. Subjek dalam penelitian ini yaitu guru dan anak usia 5-6 tahun. Usia tersebut masuk dalamiranah pendidikan anak usia dini. Oleh karena hal tersebut pendidikan sejak dini sangatlah penting untuk proses perkembangan mereka. Adapun tujuan dari penelitian ini adalah untuk mencari suatu kebenaran mengenai hubungan antara komunikasi guru dan anak pada saat pembelajaran dikelas ataupun diluar kelas dengan perilaku disiplin anak di lingkungan sekolah.

Penemuan hasil dari penelitian menunjukkan bahwa ada tiga indikator komunikasi efektif yang digunakan oleh guru memiliki nilai sama tinggi yaitu $25 \%$. Indikator tersebut yaitu pemahaman, kesenangan, dan tindakan kedua belah pihak. Pemberian pemahaman pada anak terlihat saat guru memberikan nasehat pada anak sebelum kegiatan istirahat, guru menyampaikan pesan bahwa jika membeli jajan, bungkusnya harus dibuang ke tempat sampah jika tidak, sampahsampah tersebut akan berserakan dan menjadi sarang penyakit. Informasi tersebut membuat beberapa anak patuh dan taat terhadap apa yang disampaikan guru. Senada dengan pengertian dari pemahaman itu sendiri yaitu kemampuan dalam memahami pesan secara cermat sebagaimana yang dimaksudkan oleh komunikator. Dapat dinyatakan bahwa pemahaman yang dimiliki anak sudah berkembang sesuai harapan dan mampu menangkap informasi yang dimaksudkan oleh guru.

Adapun pemberian nasehat melalui kesanangan terlihat ketika kegiatan bermain. Sebelum bermain guru memberikan aturan bahwa saat bermain pada waktu istirahat, anak-anak tidak boleh berebut menggunakan alat permainan. Mereka harus bergantian jika ingin menggunakan alat permainan yang sama, dan menjelaskan akibat jika berebut alat permainan maka akan mencelakai teman yang lain. Pengkomunikasian tersebut dilakukan dengan ekspresi yang menyenangkan seperti tersenyum, berlangsung saat suasana bermain dan tidak menunjukkan sebuah ancaman. Senada dengan pengertian dari kesenangan yakni prosesikomunikasi selain berhasil dalam penyampianipesan juga berlangsung dalamisuasana yang menyenangkan. Dapat dikatakan bahwa penerimaan informasi melalui kesenangan inilah dapat membuat anak merasa dimngerti dan tidak tertekan.

Selanjutnya yakni pengkomunikasian dengan tindakan kedua belah pihak. Hal ini terlihat pada saat kegiatan praktek sholat, sebelum praktek sholat berlangsung guru memberitahukan bahwa anak perempuan harus mengenakan mukena dan anak laki-laki mengenakan sarung serta peci. Kemudian anak-anak bergegas memakai mukena untuk perempuan dan mengenakan sarung untuk anak laki-laki, namun ada beberapa anak yang tidak mengenakan nya dikarenakan tidak membawa dari rumah. Perilaku ini menunjukkan sikap ketaatan anak terhadap apa yang dikomunikasikan oleh guru. Pernyataan tersebut senada dengan maksud dari tindakan kedua belah pihak bahwa kedua belah pihak yang berkomunikasi melakukan tindakan sesuai dengan pesan yang dikomunikasikan. Maka dari hasil rekapitulasi komunikasi antara guru dan anak ini memiliki tingkat kategori sedang. Dapat disimpulkan bahwa anak-anak sudah mampu menangkap nasehat ataupun informasi dari guru dengan baik, sehingga tingkah laku anak akan muncul sesuai yang diharapkan.

Berdasarkan indikator disiplin anak yang digunakan dalam penelitian ini, tingkah laku anak sudah terlihat ketika anak dengan sendirinya menaruh tas ataupun sepatunya pada rak yang telah tersedia. Sudah mampu 
Jurnal PG-PAUD Trunojoyo : Jurnal Pendidikan dan Pembelajaran Anak Usia Dini, Volume 6, Nomor 2, Oktober 2019, hal 70 - 76, ISSN : 2528-3553 (online), ISSN: 2407-4454 (print)

membuang sampah bungkus makanan nya ke tempat sampah, sudah mampu merapikan alat tulisnya sendiri, sudah mampu mengantre saat akan menggunakan toilet ataupun alat permainan. Hal tersebut sudah nampak dilakukan oleh anak-anak di kelompok B TK Sejahtera Kamal. Hal ini dikarenakan guru sudah membiasakannya sejak awal dan karena sudah dilatih dari rumah (lingkungan keluarga) terutama oleh orang tua anak.

Bentuk disiplin yang terjadi di sekolah TK Sejahtera Kamal lebih pada cara guru memberikan kebebasan pada anak akan tetapi anak harus menanggung konsekuensi jika melanggar peraturan yang telah ada. Senada dengan salah satu bentuk disiplin yang diungkapkan oleh Ali Imron dalam Wiyani (2013:48). Ia mengemukakan bahwa disiplin kebebasani yang bertanggungjawabi (disiplin demokratis) yang artinya memberikan kebebasani yang seluas-luasnyai kepadaianak untuk berbuat apapun, akan tetapi anak harus menanggungikonsekuensi akibatidari perbuatannyaitersebut. Dapat ditarik kesimpulan bahwasannya disiplin yang ada di TK Sejahtera Kamal termasuk dalam bentuk disiplin yang demokratis, tidak menekan anak malah memberikan kebebasan pada anak namun dengan konsekuensi tertentu.

Berdasarkan hasil dari perhitungan yang telah dilakukan dapat diketahui bahwa hipotesis nol () yang diterima dalam uji hipotesis. Hal ini berarti tidak terdapat hubungan antara komunikasi guru dan anak dengan kedisiplinan anak kelompok B2 TK Sejahtera Kamal. Hubungan komunikasi antara guru dan anak dengan kedisiplinan pada kelompok B2 TK Sejahtera Kamal dinyatakan dengan nilai $r$ sebesar 0,205 sehingga nilai KP sebesar $0,0402 \%$, yang menunjukkan hubungan rendah. Hal tersebut dipengaruhi oleh faktor lain yakni kedisiplinan anak dibiasakan sejak dalam lingkungan keluarga, terutama oleh orang tua anak seperti membiasakan untuk melepas alas kaki jika memasuki rumah yang berlantai bersih. Oleh sebab itulah pada penelitian ini terlihat bahwa ada hubungan antara komunikasi guru dan anak dengan kedisiplinan anak meskipun rendah. Dengan kata lain, tidak terdapat hubungan yang signifikan antara komunikasi guru dan anak dengan kedisiplinan anak kelompok B di TK Sejahtera Kamal.

\section{SIMPULAN}

Kegiatan komunikasi yang dilakukan oleh guru di TK Sejahtera Kamal dominan melalui komunikasi kelompok mengakibatkan anak kurang memahami maksud dan tujuan dari guru memberikan nasehat ataupun informasi. Kedisiplinan anak dilihat dari sikap patuh pada aturan yang telah dikomunikasikan oleh guru. Analisis yang dilakukan untuk mengetahui hubungan komunikasi guru dan anak dengan kedisiplinan pada kelompok B di TK Sejahtera Kamal memperoleh nilai $r=0,205$ (hubungan rendah).

Berdasarkan uji hipotesis yang dilakukan diketahui nilai $\mathrm{r}=0,205$ sehingga nilai koefisien determinan (KP) sebesar 0,042\%. Komunikasi guru dan anak memiliki hubungan sebesar $0,042 \%$ (hubungan rendah) dengan kedisiplinan pada kelompok B di TK Sejahtera Kamal. Kedisiplinan telah dibiasakan oleh orangtua saat dirumah, sehingga komunikasi antara guru dan anak memiliki hubungan yang rendah dengan kedisiplinan anak.Bagian simpulan berisi temuan penelitian yang berupa jawaban atas pertanyaan penelitian atau berupa intisari hasil pembahasan.

\section{SARAN}

Berdasarkan dari simpulan hasil penelitian, peneliti memiliki saran sebagai berikut: (a) hendaknya guru menanamkan sikap disiplin pada anak didik melalui pembiasaan sehari-hari seperti mengantre saat akan mencuci tangan, merapikan kembali alat tulis yang telah selesai digunakan, dan menaruh tas atau sepatu pada tempatnya; (b) Hendaknya orang tua di rumah ikut serta menanamkan perilaku disiplin kepada anak dengan cara yang baik dan melalui pembiasaan sehari-hari seperti membiasakan pada anak untuk merapikan alat mainannya yang sudah selesai digunakan; dan (c) Bagi peneliti selanjutnya perlu memperluas dan mengembangkan cakupan materi yang relevan pada penelitian selanjutnya.

\section{DAFTAR PUSTAKA}

Arikunto, S. (2014). Prosedur Penelitian Suatu Pendekatan Praktik. Jakarta: Rineka Cipta.

Ma'arif, U. (2012). Hubungan Antara Komunikasi Remaja Dan Orang Tua 
76 Jurnal PG-PAUD Trunojoyo : Jurnal Pendidikan dan Pembelajaran Anak Usia Dini, Volume 6, Nomor 2, Oktober 2019, hal 70-76, ISSN : 2528-3553 (online), ISSN: 2407-4454 (print)

Dan Disiplin di MAN Maguwoharjo. Skripsi. (Online). (http://digilib.uinsuka.ac.id), diakses pada tanggal 26 Februari 2019.

Mulyasa. (2012). Manajemen PAUD. Bandung: PT. Remaja Rosdakarya.

Naim, N. (2011). Dasar-Dasar Komunikasi Pendidikan. Jogjakarta: Ar-Ruzz Media.

Na'imah, T. (2005). Kecakapan Hidup (Life Skills) Peserta Didik Sekolah Menengah Kejuruan ditinjau dari Kemampuan Mengajar Guru dan Disiplin Diri Peserta Didik. Tesis. (Online).

(http://etd.repository.ugm.ac.id), diakses 26 Februari 2019.

Rimm, S. (2003). Mendidik dan Menerapkan Disiplin pada Anak Prasekolah. Jakarta: PT Gramedia Pustaka Utama.

Riduwan. (2015). Belajar Mudah Penelitian untuk Guru Karyawan Peneliti Pemula. Bandung: Alfabeta.

Sugiyono. (2014). Metode Penelitian Kuantitatif, Kualitatif, dan $R \& D$. Bandung: Alfabeta.

Suranto, A, W. (2006). Komunikasi Efektif untuk Mendukung Kinerja Sekolah. Yogyakarta: Media Wacana.

Tu'uT. (2008). Peran Disiplin Pada Perilaku dan Prestasi Siswa. Jakarta: PT. Grasindo.

Wiyani, N, A. (2013). Bina Karakter Anak Usia Dini. Jogjakarta: Ar-Ruzz Media. 